\title{
IMPROVEMENT OF QUALITY OF COPRA (DRIED KERNEL OF COCOS NUCIFERA) SEED MEAL PROTEIN WITH SUPPLEMENTAL AMINO ACIDS IN FEEDS FOR ROHU, LABEO ROHITA (HAMILTON) FINGERLINGS
}

\author{
POPRAWA JAKOŚCI KOPRY (SUSZONY MIĄŻSZ ORZECHA COCOS \\ NUCIFERA) WZBOGACONEJ AMINOKWASAMI W PASZACH DLA \\ PALCZAKÓW GRUBOWARGA, LABEO ROHITA (HAMILTON)
}

\begin{abstract}
Fisheries Laboratory, Department of Zoology, Visva-Bharati University, Santiniketan,
\end{abstract} West Bengal, India

An eight-week feeding trial was conducted in a static indoor rearing system to examine the effects of partial substitution of fish meal (FM) protein with copra meal protein with and without supplemental amino acids in diets for rohu, Labeo rohita fingerlings (average weight $5.50 \pm 0.19 \mathrm{~g}$ ).Prior to incorporation into diets, the meal was fermented with lactic acid bacteria (Lactobacillus acidophilus) in order to reduce / eliminate the anti-nutritional factors, tanin and phytic acid present in it. Twelve experimental diets (D1 to D12) were formulated replacing the FM protein from a reference diet with copra meal protein at different levels (four sets of diets, of which each set of three diets contained 30,40, and 50\% replacement of FM protein by copra meal protein respectively). Diets D1 to D3 were not supplemented with any amino acid. Lysine was added to diets D4 to D6. Diets D7 to D9 were supplemented with methionine-cystine (together) and diets D10 to D12 contained lysine and methionine-cystine (together). Lysine and methionine-cystine (together) were added to the diets at $5.7 \%$ and $3.1 \%$ of dietary protein respectively. The groups of fish fed diets without any supplemental amino-acids had significantly lower percentage weight gain, SGR and high FCR than the groups of fish fed other experimental diets. The addition of lysine and methionine-cystine to the diet in which $50 \%$ of FM protein was replaced by copra protein (diet D12) significantly improved fish weight gain and FCR. The percentage live weight gain and SGR values differed significantly $(\mathrm{P}<0.01)$ from each other in the fish fed diets D10 to D12 which were supplemented with all three amino acids. The results of the present study suggest that rohu fingerlings can effectively utilise the supplemented amino acids and that copra meal protein can replace up to $50 \%$ of $\mathrm{FM}$ protein in the diets for rohu if the meal is properly fermented and supplemented with deficient amino acids. 


\section{INTRODUCTION}

Attempts to totally replace the fish meal component in aquafeeds with alternate individual protein sources have met with little success. It is therefore, a common practice to attempt to improve the protein quality of aquafeeds by supplementing with the essential amino acids (EAA) that are in greatest deficit (Teshima and Kanazawa 1988; Robinson 1991; Webster et al. 1995). Some EAA, such as methionine and lysine, are generally critical in formulating fish diets with inexpensive plant protein sources (Tacon 1985). While fish and shrimps do not thrive well on mixture of pure synthetic amino acids instead of protein, individual amino acids (notably L-lysine and DL-methionine) can effectively be used to supplement diets otherwise deficient in these amino acids (New 1987). Most plant proteins are deficient in the sulphur amino acids (methionine and cystine). The lysine requirement of carp is relatively high, $5.7 \%$ of the total protein (NRC-NAS 1983; Wilson 1985). There exists a relationship between methionine and cystine, two important sulphur-containing amino acids. Cystine is considered non essential because it can be synthesised by the fish from the essential amino acids, methionine.

Therefore, if methionine is fed without cystine, a portion of methionine is used for protein synthesis and a portion is converted to cysteine for incorporation into protein as cystine. If cystine is included into the diet, it reduces the amount of methionine needed in the diet. Because of this relationship, the fish has a total sulphur amino acid requirement rather than a specific methionine requirement. The total sulphur amino acid requirement (methionine + cystine) for carp has been reported to be 3.1\% of total protein (Nose 1979; Wilson 1985).

Copra (dried kernel of coconut, Cocos mucifera) is available at a large scale in Birbhum, West Bengal, India as a by-products of coconut oil industry. Although deoiled copra meal is a promising vegetable source in carp diets (Mukhopadhyay and Ray 1999), yet it is low in methionine and lysine. In the present study, diets containing different inclusion levels of deoiled copra meal protein were supplemented with lysine and methionine-cystine (together) to meet the minimum requirement for lysine and methioninecystine for carp which are $5.7 \%$ and $3.1 \%$ of dietary protein respectively (Nose 1979; NRCNAS 1983; Wilson 1985).

\section{MATERIAL AND METHODS}

\section{Experimental diets}

Fermented copra meal was used as the test ingredient. Autoclaved samples of copra meal were then inoculated with lactic bacteria, Lactobacillus acidophilus (Intercare Ltd., India; $10^{6}$ cells $/ \mathrm{g}$ ) at $5 \%$ level and kept for 48 hours at room temperature. After 48 hours the fermented sample was sundried and pulverised. The fermented samples were analysed 
for phytic acid content and were found to be reduced below the detection limit. Twelve experimental diets (diets D1 to D12) were prepared replacing fish meal protein with copra meal protein at different levels. In diets D1, D2, and D3 fish meal protein was replaced by copra meal protein at 30,40 , and $50 \%$ levels without any amino acid supplementation. Diets D4, D5, and D6 were supplemented with lysine at $5.7 \%$ of dietary protein. Diets D7, D8, and D9 were supplemented with methionine and cystine (together) at $3.1 \%$ level of dietary protein. Finally, diets D10, D11, and D12 were supplemented with all three amino acids, i.e., lysine, methionine and cystine. To each of the formulated diets $1 \%$ chromic oxide was added as an external marker. All the diets were prepared in pelleted form using carboxymethyl celulose (CMC) as a binder (Tab. 1).

\section{Experimental design}

The experiment was conducted in a static indoor rearing system containing $90-\mathrm{dm}^{3}$ glass aquaria with continuous aeration. Rohu, Labeo rohita fingerlings were obtained from a local fish seed dealer and acclimated to the laboratory condition for 15 days and fed with a 1:1 mixture of rice bran and mustard oilcake. Fish fingerlings (mean weight $5.50 \pm 0.17 \mathrm{~g}$ ) were randomly distributed at the rate of 10 fish per aquarium with two replicates for each treatment. Each experimental aquarium was supplied with unchlorinated water from a deep tube well. The experimental fish were fed with the formulated diets twice daily at $09.00 \mathrm{~h}$ and $15.00 \mathrm{~h}$ at a fixed feeding rate of $5 \%$ wet body weight per day for the whole experimental period of 60 days duration. The quantity of feed given was readjusted every $10^{\text {th }}$ day after weighing the fish. The uneaten feed was collected after $1 \mathrm{~h}$ by siphoning after each feeding. The faecal samples were collected following the method outlined by Spyridakis et al. (1989). The faeces naturally released by the fish could be easily detectable and were removed from the water with a glass canula. The collection was performed everyday, $17 \mathrm{~h}$ after the last feeding. Faeces collected from replicate treatments were pooled, dried at $60^{\circ} \mathrm{C}$ in an oven and stored for subsequent analysis. Pooled faecal samples for each treatment were analysed separately. At the termination of the experiment, all the fish were weighed individually and used for subsequent analysis. The water in each tank was changed every day throughout the experimental period in order to maintain the water quality. The ranges of the water quality parameters were: temperature, $26-30^{\circ} \mathrm{C} ; \mathrm{pH}$, 6.3-7.3; dissolved oxygen, 4.9-7.7 mg/ $\mathrm{dm}^{3}$; alkalinity, $189-190 \mathrm{mg} / \mathrm{dm}^{3}$. 
Table 1

Ingredient composition (\% dry weight) and proximate composition of the experimental diets (on dry matter basis)

\begin{tabular}{|c|c|c|c|c|c|c|c|c|c|c|c|c|c|}
\hline \multirow{2}{*}{ Ingredients } & \multicolumn{13}{|c|}{ Diets } \\
\hline & $\mathrm{RD}$ & D1 & D2 & D3 & D4 & D5 & D6 & D7 & D8 & D9 & D10 & D11 & D12 \\
\hline Fish meal & 50.00 & 34.99 & 30.00 & 25.00 & 34.99 & 30.00 & 25.00 & 34.99 & 30.00 & 25.00 & 34.99 & 30.00 & 25.00 \\
\hline Copra meal & - & 38.15 & 50.00 & 63.00 & 38.15 & 50.00 & 63.00 & 38.15 & 50.00 & 63.00 & 38.15 & 50.00 & 63.00 \\
\hline Mustard oilcake & 18.00 & 16.00 & 16.00 & 8.00 & 16.00 & 14.39 & 6.33 & 16.00 & 15.29 & 7.31 & 16.00 & 13.68 & 5.64 \\
\hline Dextrin & 28.00 & 6.86 & - & - & 5.29 & - & - & 6.13 & - & - & 4.56 & - & - \\
\hline Cod liver oil & 1.00 & 1.00 & 1.00 & 1.00 & 1.00 & 1.00 & 1.00 & 1.00 & 1.00 & 1.00 & 1.00 & 1.00 & 1.00 \\
\hline Sunflower oil & 1.00 & 1.00 & 1.00 & 1.00 & 1.00 & 1.00 & 1.00 & 1.00 & 1.00 & 1.00 & 1.00 & 1.00 & 1.00 \\
\hline Lysine & - & - & - & - & 1.57 & 1.61 & 1.67 & - & - & - & 1.51 & 1.61 & 1.67 \\
\hline Methionine & - & - & - & - & - & - & - & 0.365 & 0.355 & 0.345 & 0.365 & 0.355 & 0.345 \\
\hline Cystine & - & - & - & - & - & - & - & 0.365 & 0.355 & 0.345 & 0.365 & 0.355 & 0.345 \\
\hline Premix* & 1.00 & 1.00 & 1.00 & 1.00 & 1.00 & 1.00 & 1.00 & 1.00 & 1.00 & 1.00 & 1.00 & 1.00 & 1.00 \\
\hline $\mathrm{Cr}_{2} \mathrm{O}_{3}$ & 1.00 & 1.00 & 1.00 & 1.00 & 1.00 & 1.00 & 1.00 & 1.00 & 1.00 & 1.00 & 1.00 & 1.00 & 1.00 \\
\hline Parameter & \multicolumn{13}{|c|}{ Proximate composition (\% dry matter) } \\
\hline Moisture & 3.95 & 8.10 & 9.45 & 9.86 & 8.07 & 9.20 & 9.63 & 8.12 & 9.35 & 9.70 & 8.03 & 9.12 & 9.49 \\
\hline Dry matter & 96.05 & 91.90 & 90.55 & 90.14 & 91.93 & 90.80 & 90.37 & 91.88 & 90.65 & 90.30 & 91.97 & 90.88 & 90.51 \\
\hline Crude protein & 35.60 & 35.01 & 34.90 & 34.79 & 34.99 & 34.92 & 34.63 & 35.02 & 35.01 & 34.72 & 34.98 & 35.03 & 34.77 \\
\hline Lipid & 7.68 & 11.17 & 12.20 & 12.91 & 11.15 & 12.14 & 12.82 & 11.19 & 12.18 & 12.87 & 11.16 & 12.09 & 12.77 \\
\hline Ash & 7.26 & 7.45 & 7.53 & 6.99 & 7.46 & 7.38 & 6.87 & 7.40 & 7.48 & 6.96 & 7.39 & 7.35 & 6.87 \\
\hline Crude fibre & 2.97 & 4.48 & 5.34 & 5.58 & 4.75 & 5.26 & 5.45 & 4.70 & 5.32 & 5.55 & 4.77 & 5.22 & 5.40 \\
\hline Nitrogen-free extract & 42.54 & 33.49 & 30.58 & 29.87 & 33.58 & 31.11 & 30.62 & 33.57 & 30.66 & 30.20 & 33.67 & 31.19 & 30.70 \\
\hline Gross energy $(\mathrm{kcal} / \mathrm{g})$ & 4.60 & 4.60 & 4.60 & 4.64 & 4.60 & 4.61 & 4.65 & 4.61 & 4.60 & 4.64 & 4.61 & 4.61 & 4.65 \\
\hline Organic matter & 88.78 & 84.45 & 83.02 & 83.15 & 84.47 & 83.42 & 83.50 & 84.48 & 83.17 & 83.34 & 84.58 & 83.53 & 83.64 \\
\hline $\mathrm{Cr}_{2} \mathrm{O}_{3}$ & 0.81 & 0.79 & 0.80 & 0.83 & 0.79 & 0.81 & 0.72 & 0.85 & 0.78 & 0.83 & 0.79 & 0.81 & 0.82 \\
\hline Tannin (\%) & - & 0.42 & 0.53 & 0.72 & 0.40 & 0.59 & 0.71 & 0.40 & 0.57 & 0.75 & 0.42 & 0.51 & 0.69 \\
\hline Phytic acid (\%) & - & - & - & - & - & - & - & - & - & - & - & - & - \\
\hline
\end{tabular}

*._- vitamin and mineral mixture (Vitamines forte, Roches India Ltd.) 


\section{Chemical and statistical analyses}

Feed ingredients, experimental diets, faecal samples, and carcasses were analysed for proximate composition following the AOAC (1990) procedures. Chromic oxide in the diets and faeces was estimated spectrophotometrically following the method of Bolin et al. (1952). The tannin content in the deoiled copra meal was determined using Folin-Denis reagent (Schanderi 1970), and the phytic acid was determined following the method outlined by Wheeler and Ferrel (1971). Amino-acid analysis of deoiled copra meal was carried out using an HPLC apparatus with PICO-TAG amino-acid analyser (Waters). Protein samples were hydrolysed in $6 \mathrm{~mol} / \mathrm{dm}^{3} \mathrm{HCl}$ at $110^{\circ} \mathrm{C}$ for $22 \mathrm{~h}$. Water analyses followed the methods outlined by the APHA (1980). Apparent protein digestibility (APD, $\%$ ) specific growth rate (SGR, \%/day), feed conversion rate (FCR), protein efficiency ratio (PER), and apparent net protein utilisation (ANPU, \%) were calculated using standard methods (Steffens 1989). Statistical analyses of the data were made by analysis of variance (ANOVA) followed by Scheffe's F-test for multiple comparisons (Das and Das 1993). Data were considered significant at the 0.01 level.

\section{RESULTS}

The proximate composition and amino acid constituents of the feed ingredients are presented in Tab. 2. The proximate composition and the calculated level of amino acids of the formulated diets are depicted in Tabs. 1 and 3, respectively. All the diets were isonitrogenous (35\% crude protein) and isocaloric ( $4.62 \mathrm{kcal} / \mathrm{g})$. Phytic acid could not be detected in any of the experimental diet. The tanin contents in the diet varied from $0.40 \%$ to $0.69 \%$.

The data pertaining to the growth performance and feed conversion efficiency of the fish in each dietary treatment are presented in Tab. 4. The average final weight of the fish increased considerably from the initial value $(5.50 \pm 0.17 \mathrm{~g})$ in all the dietary treatments. However, the highest attainment in fish body weight, average percentage live weight gain, and SGR were recorded in the group of fish reared on diet D12 with $50 \%$ copra meal protein and supplemented with lysine, methionine and cystine. The percentage live weight gain and SGR of the fish fed diets without any amino acid supplementation (diets D1 to D3) and with only lysine supplementation (diets D4 to D6) decreased with increasing levels of fish meal protein replacement with copra meal protein. Best PER was recorded in the fish fed diet D12. PER value was lowest with diet D3 (50\% fish meal protein replaced by fermented copra meal, without any amino acid supplementation) which was not significantly different from that obtained with diet D2. Apparent net protein utilisation (ANPU) by the fish was recorded with diet D12 while, the lowest was recorded with diet D3. The feed conversion ratio (FCR) was best for diet D12 which was significantly different from all other diets. The FCR was worse with diet D3 (with 50\% fish meal protein replacement and 
without any amino acid supplementation). The apparent protein digestibility from diet D9 was comparable to the reference diet and diet D12 had significantly $(P<0.01)$ higher protein digestibility than the reference diet. The apparent protein digestibility of D12 was comparable to the diets D10 and D12. Protein digestibility from the copra meal was lowest with diet D3 (50\% replacement level without any amino acid supplementation).

Table 2

Proximate composition and amino acid constituents of feed ingredients (\% dry matter basis)

\begin{tabular}{|c|c|c|c|}
\hline Nutrients & Fish meal * & Mustard oilcake* & Copra meal \\
\hline Moisture & 2.96 & 14.00 & 12.70 \\
\hline Dry matter & 97.04 & 86.00 & 87.30 \\
\hline Crude protein & 58.50 & 35.93 & 23.00 \\
\hline Lipid & 9.91 & 7.00 & 12.91 \\
\hline Ash & 11.50 & 8.37 & 5.50 \\
\hline Crude fibre & 3.93 & 5.53 & 6.60 \\
\hline Nitrogen-free extract (NFE) & 14.20 & 29.17 & 39.29 \\
\hline Total carbohydrate & 18.13 & 34.70 & 45.89 \\
\hline Gross energy $(\mathrm{kca} / \mathrm{g})$ & 4.19 & 4.11 & 4.40 \\
\hline Tannin & - & - & 2.40 \\
\hline Phytic acid & - & - & 0.20 \\
\hline \multicolumn{4}{|l|}{ Amino acids } \\
\hline Arginine & $3.77(6.11)^{1}$ & $1.90(5.80)$ & $3.54(15.4)$ \\
\hline Cystine & $0.60(0.97)$ & $0.44(1.84)$ & $0.30(1.3)$ \\
\hline Histidine & $1.61(2.60)$ & $0.88(2.68)$ & $0.78(3.4)$ \\
\hline Isoleucine & $3.10(5.02)$ & $1.28(3.91)$ & $1.45(6.3)$ \\
\hline Leucine & $4.99(8.08)$ & $2.31(7.05)$ & $0.92(4.0)$ \\
\hline Lysine & $5.04(8.17)$ & $1.85(5.04)$ & $0.23(1.0)$ \\
\hline Methionine & $1.99(3.22)$ & $0.69(2.10)$ & $0.46(2.0)$ \\
\hline Phenyloalanine & $2.78(4.51)$ & $1.48(4.82)$ & $0.46(2.0)$ \\
\hline Threonine & $2.76(4.47)$ & $1.80(4.50)$ & $0.99(4.3)$ \\
\hline Valine & $3.50(5.67)$ & $1.54(4.70)$ & $0.92(4.0)$ \\
\hline Tyrosine & $2.24(3.63)$ & $1.19(3.63)$ & $0.14(0.6)$ \\
\hline
\end{tabular}

* Amino acid composition of fish meal according to National Research Council (1983) and mustard oilcake according to Capper et al. (1982)

'Figures in parentheses indicate the amino acid contents expressed as \% of protein

Proximate carcass composition of fish fed different experimental diet is presented in Tab. 5. The moisture content of the carcass was found to decrease as compared to the initial value with all dietary treatments except with diets D1, D2, D3, D4, D5, D6. The deposition of protein and lipid in the carcass of the experimental fish increased over the initial value. Highest accumulation of protein was recorded in the carcass of the fish reared on diet D12 which significantly differed $(P<0.01)$ from all other. 
Table 3

Calculated level of amino acids in experimental diets (\% dry matter basis)

\begin{tabular}{|c|c|c|c|c|c|c|c|c|c|c|c|c|c|}
\hline \multirow{2}{*}{ Amino acids } & \multicolumn{13}{|c|}{ Diet no. } \\
\hline & $\mathrm{RD}$ & D1 & $\mathrm{D} 2$ & D3 & D4 & D5 & D6 & D7 & D8 & D9 & D10 & D11 & D12 \\
\hline Arginine & 2.34 & 3.26 & 3.68 & 3.70 & 3.26 & 3.51 & 3.67 & 3.26 & 3.66 & 3.69 & 3.26 & 3.50 & 3.65 \\
\hline Cystine & 0.40 & 0.43 & 0.44 & 0.41 & 0.43 & 0.43 & 0.40 & 0.79 & 0.79 & 0.75 & 0.79 & 0.78 & 0.74 \\
\hline Histidine & 1.01 & 1.09 & 1.11 & 1.06 & 1.09 & 1.09 & 1.04 & 1.09 & 1.10 & 1.05 & 1.09 & 1.08 & 1.04 \\
\hline Isoleucine & 1.87 & 1.99 & 2.03 & 1.96 & 1.99 & 2.00 & 1.94 & 1.99 & 2.02 & 1.95 & 1.99 & 1.99 & 1.93 \\
\hline Leucine & 3.05 & 2.63 & 2.50 & 2.16 & 2.63 & 2.46 & 2.12 & 2.63 & 2.48 & 2.15 & 2.63 & 2.44 & 2.10 \\
\hline Lysine & 2.98 & 2.26 & 2.03 & 1.64 & 3.83 & 3.61 & 3.27 & 2.26 & 2.02 & 1.62 & 3.77 & 3.59 & 3.26 \\
\hline Methionine & 1.17 & 1.05 & 1.01 & 0.91 & 1.05 & 0.99 & 0.90 & 1.41 & 1.36 & 1.25 & 1.41 & 1.34 & 1.23 \\
\hline Phenyloalanine & 1.74 & 1.48 & 1.40 & 1.19 & 1.48 & 1.37 & 1.16 & 1.48 & 1.39 & 1.17 & 1.48 & 1.36 & 1.15 \\
\hline Threonine & 1.80 & 1.76 & 1.46 & 1.59 & 1.76 & 1.72 & 1.56 & 1.76 & 1.74 & 1.58 & 1.76 & 1.71 & 1.54 \\
\hline Valine & 2.13 & 1.95 & 1.90 & 1.71 & 1.95 & 1.87 & 1.68 & 1.95 & 1.88 & 1.70 & 1.95 & 1.85 & 1.67 \\
\hline Tyrosine & 1.40 & 1.09 & 0.99 & 0.79 & 1.09 & 0.97 & 0.77 & 1.09 & 0.98 & 0.78 & 1.09 & 0.96 & 0.76 \\
\hline
\end{tabular}


Growth, feed utilization efficiencies and apparent protein digestibility (ADP) in Labeo rohita fed experimental diets for 60 days

\begin{tabular}{|c|c|c|c|c|c|c|c|c|c|c|c|c|c|}
\hline \multirow{2}{*}{ Parameter } & \multicolumn{13}{|c|}{ Diets } \\
\hline & RD & D1 & D2 & D3 & D4 & D5 & D6 & D7 & D8 & D9 & Dl0 & Dll & D12 \\
\hline No. of test fishes & 10 & 10 & 10 & 10 & 10 & 10 & 10 & 10 & 10 & 10 & 10 & 10 & 10 \\
\hline \multirow{2}{*}{ Av. init. body wt. (g) } & $5.50^{\mathrm{a}}$ & $5.50^{\mathrm{a}}$ & $5.50^{\mathrm{a}}$ & $5.50^{2}$ & $5.50^{a}$ & $5.50^{3}$ & $5.50^{\mathrm{g}}$ & $5.50^{\circ}$ & $5.50^{\mathrm{a}}$ & $5.50^{\mathrm{a}}$ & $5.50^{8}$ & $5.50^{2}$ & $5.50^{\mathrm{a}}$ \\
\hline & \pm 0.17 & \pm 0.17 & \pm 0.17 & \pm 0.17 & \pm 0.17 & \pm 0.17 & \pm 0.17 & \pm 0.17 & \pm 0.17 & \pm 0.17 & \pm 0.17 & \pm 0.17 & \pm 0.17 \\
\hline \multirow{2}{*}{ Final av. wt. gain (g) } & $11.71^{8}$ & $10.43^{\circ}$ & $10.33^{3}$ & $10.27^{\mathrm{s}}$ & $10.83^{\mathrm{d}}$ & $10.82^{\star}$ & $10.65^{\circ}$ & $10.91^{\mathrm{d}}$ & $11.18^{\mathrm{e}}$ & $11.45^{\mathrm{t}}$ & $11.83^{g}$ & $12.10^{\mathrm{h}}$ & $12.65^{\prime}$ \\
\hline & \pm 0.11 & \pm 0.09 & \pm 0.07 & \pm 0.03 & \pm 0.04 & \pm 0.05 & \pm 0.01 & \pm 0.09 & \pm 0.09 & \pm 0.07 & \pm 0.06 & \pm 0.04 & \pm 0.01 \\
\hline Net. wt. gain (g) & 6.21 & 4.93 & 4.83 & 4.77 & 5.33 & 5.32 & 5.15 & 5.41 & 5.68 & 5.95 & 6.33 & 6.60 & 7.15 \\
\hline \multirow{2}{*}{ Live wt. gain (g) } & $112.91^{\mathrm{g}}$ & $89.59^{b}$ & $87.81^{\circ}$ & $86.77^{2}$ & $96.81^{d}$ & $96.75^{\prime \prime}$ & $93.57^{c}$ & $98.44^{d}$ & $103.20^{\circ}$ & $108.23^{f}$ & $115.00^{B}$ & $120.00^{h}$ & $130.00^{1}$ \\
\hline & \pm 0.11 & \pm 0.12 & \pm 0.09 & \pm 0.09 & \pm 0.08 & \pm 0.12 & \pm 0.09 & \pm 0.09 & \pm 0.12 & \pm 0.11 & \pm 0.12 & \pm 0.09 & \pm 0.10 \\
\hline \multirow{2}{*}{$\begin{array}{l}\text { Sp. gr. rate (SGR) } \\
\left(\% \cdot \text { day }^{-1}\right)\end{array}$} & $1.26^{8}$ & $1.07^{b}$ & $1.05^{3}$ & $1.04^{\mathrm{B}}$ & $1.13^{d}$ & $1.12^{\mathrm{d}}$ & $1.10^{\circ}$ & $1.14^{\mathrm{d}}$ & $1.18^{\mathrm{e}}$ & $1.22^{\mathrm{t}}$ & $1.27^{8}$ & $1.31^{\mathrm{h}}$ & $1.39^{1}$ \\
\hline & \pm 0.06 & \pm 0.02 & \pm 0.04 & \pm 0.02 & \pm 0.01 & \pm 0.06 & \pm 0.09 & \pm 0.07 & \pm 0.02 & \pm 0.04 & \pm 0.01 & \pm 0.06 & \pm 0.07 \\
\hline \multirow{2}{*}{ FCR } & $2.20^{\mathrm{c}}$ & $2.59^{1}$ & $2.62^{B}$ & $2.65^{8}$ & $2.41^{e}$ & $2.45^{\mathrm{e}}$ & $2.51^{\mathrm{t}}$ & $2.31^{\mathrm{d}}$ & $2.25^{\mathrm{c}}$ & $2.22^{\mathrm{C}}$ & $2.12^{\circ}$ & $2.10^{\circ}$ & $2.04^{8}$ \\
\hline & \pm 0.09 & \pm 0.01 & \pm 0.03 & \pm 0.01 & \pm 0.04 & \pm 0.02 & \pm 0.06 & \pm 0.02 & \pm 0.04 & \pm 0.06 & \pm 0.02 & \pm 0.04 & \pm 0.03 \\
\hline \multirow{2}{*}{ PER } & $1.28^{\mathrm{I}}$ & $1.10^{\mathrm{b}}$ & $1.09^{\circ}$ & $1.09^{\mathrm{a}}$ & $1.19^{d}$ & $1.17^{\mathrm{c}}$ & $1.15^{\mathrm{c}}$ & $1.24^{\mathrm{C}}$ & $1.27^{\mathrm{t}}$ & $1.30^{8}$ & $1.34^{\mathrm{h}}$ & $1.36^{1}$ & $1.41^{\mathrm{J}}$ \\
\hline & \pm 0.01 & \pm 0.04 & \pm 0.02 & \pm 0.03 & \pm 0.05 & \pm 0.01 & \pm 0.02 & \pm 0.01 & \pm 0.04 & \pm 0.02 & \pm 0.04 & \pm 0.03 & \pm 0.02 \\
\hline \multirow{2}{*}{ ANPU (\%) } & $23.87^{h}$ & $10.96^{c}$ & $9.30^{\circ}$ & $8.66^{a}$ & $15.59^{\mathrm{e}}$ & $13.41^{\mathrm{d}}$ & $11.86^{c}$ & $19.68^{t}$ & $21.25^{\mathrm{g}}$ & $22.71^{8}$ & $26.01^{2}$ & $26.19^{1}$ & $26.43^{3}$ \\
\hline & \pm 0.10 & \pm 0.09 & \pm 0.08 & \pm 0.11 & \pm 0.04 & \pm 0.06 & \pm 0.09 & \pm 0.08 & \pm 0.06 & \pm 0.05 & \pm 0.07 & \pm 0.06 & \pm 0.07 \\
\hline \multirow{2}{*}{ APD (\%) } & $89.16^{c}$ & $83.61^{\circ}$ & $81.35^{a}$ & $80.75^{\mathrm{a}}$ & $87.66^{b}$ & $87.19^{b}$ & $86.42^{\circ}$ & $88.53^{c}$ & $88.72^{\circ}$ & $89.09^{c}$ & $90.04^{d}$ & $90.19^{d}$ & $90.92^{d}$ \\
\hline & \pm 0.11 & \pm 0.16 & \pm 0.20 & \pm 0.21 & \pm 0.20 & \pm 0.24 & \pm 0.22 & \pm 0.23 & \pm 0.16 & \pm 0.11 & \pm 0.20 & \pm 0.30 & \pm 0.20 \\
\hline
\end{tabular}

Figures with same superscripts in the same row was not significantly different $(P<0.01)$ 
Table 5

Proximate carcass composition of Labeo rohita fingerlings fed experimental diets for 60 days \% wet weight)

\begin{tabular}{|c|c|c|c|c|c|c|c|c|c|c|c|c|c|c|}
\hline \multirow{2}{*}{ Parameter } & \multicolumn{14}{|c|}{ Diets } \\
\hline & Initial & $\mathrm{RD}$ & D1 & $\mathrm{D} 2$ & D3 & $\mathrm{D} 4$ & D5 & D6 & D7 & D8 & D9 & D10 & D11 & D12 \\
\hline \multirow{2}{*}{ Moisture } & \multirow{2}{*}{80.21} & $79.95^{b}$ & $81.49^{f}$ & $81.52^{f}$ & $81.70^{\mathrm{g}}$ & $80.60^{d}$ & $80.70^{d}$ & $81.10^{\mathrm{e}}$ & $80.30^{\circ}$ & $80.20^{c}$ & $79.98^{b}$ & $79.92^{6}$ & $78.83^{\mathrm{a}}$ & $79.81^{\mathrm{a}}$ \\
\hline & & \pm 0.20 & \pm 0.21 & \pm 0.19 & \pm 0.14 & \pm 0.15 & \pm 0.11 & \pm 0.15 & \pm 0.21 & \pm 0.19 & \pm 0.18 & \pm 0.21 & \pm 0.19 & \pm 0.20 \\
\hline \multirow{2}{*}{ Dry matter } & \multirow{2}{*}{19.79} & $20.05^{\mathrm{e}}$ & $18.51^{b}$ & $18.48^{b}$ & $18.21^{\mathrm{a}}$ & $19.31^{\mathrm{c}}$ & $19.23^{c}$ & $18.89^{c}$ & $19.64^{\mathrm{d}}$ & $19.76^{\mathrm{d}}$ & $20.02^{e}$ & $20.08^{e}$ & $20.17^{f}$ & $20.19^{f}$ \\
\hline & & \pm 0.09 & \pm 0.10 & \pm 0.08 & \pm 0.09 & \pm 0.09 & \pm 0.10 & \pm 0.08 & \pm 0.09 & \pm 0.10 & \pm 0.09 & \pm 0.07 & \pm 0.08 & \pm 0.10 \\
\hline \multirow{2}{*}{ Protein } & \multirow{2}{*}{7.32} & $8.70^{f}$ & $8.27^{b}$ & $8.19^{\mathrm{a}}$ & $8.10^{\mathrm{a}}$ & $8.49^{\mathrm{d}}$ & $8.43^{c}$ & $8.38^{\mathrm{c}}$ & $8.55^{\mathrm{e}}$ & $8.59^{\mathrm{e}}$ & $8.62^{\mathrm{e}}$ & $8.72^{f}$ & $8.89^{\mathrm{g}}$ & $8.91^{\mathrm{g}}$ \\
\hline & & \pm 0.06 & \pm 0.09 & \pm 0.07 & \pm 0.11 & \pm 0.09 & \pm 0.04 & \pm 0.06 & \pm 0.08 & \pm 0.09 & \pm 0.10 & \pm 0.09 & \pm 0.01 & \pm 0.01 \\
\hline \multirow{2}{*}{ Lipid } & \multirow{2}{*}{3.87} & $5.03^{g}$ & $4.36^{b}$ & $4.28^{\mathrm{a}}$ & $4.25^{\mathrm{a}}$ & $4.57^{\mathrm{d}}$ & $4.48^{\mathrm{c}}$ & $4.40^{\mathrm{c}}$ & $4.73^{\mathrm{e}}$ & $4.82^{\mathrm{f}}$ & $4.91^{\mathrm{f}}$ & $5.09^{\mathrm{g}}$ & $5.14^{h}$ & $5.2 .1^{\mathrm{h}}$ \\
\hline & & \pm 0.09 & \pm 0.07 & \pm 0.11 & \pm 0.11 & \pm 0.13 & \pm 0.11 & \pm 0.09 & \pm 0.11 & \pm 0.05 & \pm 0.06 & \pm 0.11 & \pm 0.09 & \pm 0.09 \\
\hline \multirow{2}{*}{ Ash } & \multirow{2}{*}{3.24} & $3.45^{\mathrm{d}}$ & $3.36^{\mathrm{c}}$ & $3.21^{\mathrm{b}}$ & $3.11^{\mathrm{a}}$ & $3.38^{\mathrm{d}}$ & $3.24^{b}$ & $3.19^{b}$ & $3.41^{\mathrm{d}}$ & $3.28^{\mathrm{c}}$ & $3.13^{\mathrm{a}}$ & $3.31^{\mathrm{c}}$ & $3.18^{b}$ & $3.09^{\mathrm{a}}$ \\
\hline & & \pm 0.07 & \pm 0.09 & \pm 0.09 & \pm 0.08 & \pm 0.10 & \pm 0.10 & \pm 0.09 & \pm 0.06 & \pm 0.07 & \pm 0.09 & \pm 0.10 & \pm 0.09 & \pm 0.10 \\
\hline
\end{tabular}

Figures with same superscripts in the same row was not significantly different $(\mathrm{P}<0.01)$ 


\section{DISCUSSION}

The results of the present study demonstrated that the supplemental amino acids (lysine and methionine + cystine) were effective in improving the nutritive value of the fermented deoiled copra meal incorporated diets which were deficient in the aforementioned amino acids for Labeo rohita fingerlings in tenns of percent weight gain, specific growth rate (SGR, \%/day), FCR, PER, and ANPU. Rohu fingerlings grew poorly when fed diets containing different levels of copra meal protein $(30,40$, and $50 \%$ replacement of fish meal protein) without any amino acid supplementation. Replacement of fish meal protein with plant protein has had variable success. In the studies where growth is reduced, several hypotheses have been suggested to explain the results. These are: (a) sub optimal amino acid balance, (b) low protein content, and (c) presence of antinutritional factors (Tacon 1993). Amino acid analyses of the oilseed meals used in the present experiments indicated that copra meal was deficient of lysine and methionine which failed to meet the amino acid requirement of rohu fingerlings. The antinutritional factors tannin and phytic acid in raw oilseed meals adversely affect the growth of fish (Mukhopadhyay and Ray 1996, 1997, 1999). The oilseed meals used in the present study was fermented with lactic acid bacteria prior to incorporation into diets. This treatment resulted in reduction of the antinutritional factors below detectable limits. The reduced growth of fish fed diets without any amino acid supplementation may be due to amino acid imbalance in these diets.

Labeo rohita fingerlings fed oilsoed meals diets with individual supplementation of lysine or methionine and cystine, had significantly lower percentage weight gain, SGR, PER, ANPU, and higher FCR than fish fed the fish meal based reference diet without any amino acid supplementation. This indicates that the supplementation of any one of the deficient amino acids did not improve the nutritional quality of the oilseed meals significantly. Rumsey and Ketola (1975) reported that individual supplementation of soybean meal with lysine, methionine, histidine or leucine did not improve growth rate of rainbow trout. In a subsequent report, Fordiani and Ketola (1980) found that methionine supplementation of commercial soybean meal improved growth rate of rainbow trout, but methionine supplementation did not improve the quality of reheated soybean meal. Wu and Jan (1977) for Oreochromis aureus fry also reported that weight gains were not increased by the supplementation of crystalline methionine to a soybean meal diet. Addition of supplemental methionine in fish diets has had variable success. Tacon et al. (1984) stated that addition of $0.2 \% \mathrm{~L}$-methionine to a diet deficient in methionine for rainbow trout, Oncorhynchus mykiss, did not improve growth. However, Shiau et al. (1987) reported that addition of supplemental methionine improved growth in tilapia. Murai et al. (1986) reported that nutritional value of soyflour was improved by addition of $0.4 \%$ crystalline L-methionine. On the contrary, Andrews and Page (1974) reported no improvement in 
weight gains when supplemental methionine was added to channel catfish diet. It has been stated that crystalline methionine is rapidly absorbed in fish and degraded into methionine sulphoxide (Thebault 1985; Murai et al. 1986). Robinson (1991) however, reported improved growth in channel catfish fed a diet in which $100 \%$ of soybean meal protein was replaced by cotton seed meal protein with supplemental lysine. Viola et al. (1982) also reported improvement of soybean meal protein with supplementation of both methionine and lysine in carp diets.

On the other hand the supplementation of the oilseed meal containing diets with lysine, methionine, and cystine was effective in improving the growth of Labeo rohita fingerlings. The fish fed diets in which $50 \%$ of fish meal protein was replaced by oilseed meal protein and supplemented with all of three amino acid (lysine, methionine, and cystine), gave significantly $(\mathrm{P}<0.01)$ the higher percentage weight gain, SGR, PER, and ANPU than those fed the reference and other experimental diets. Andrews and Page (1974) tried to improve the quality of soybean protein by adding methionine, cystine or lysine. They found, however, that adding crystalline methionine, cystine or lysine did not improve the growth of channel catfish.

Although essential amino acid requirements of Labeo rohita fingerlings have not been established, the results of the present study indicate that the diets containing $50 \%$ oilseed meal protein with amino acid supplementation (lysine and methionine + cystine) met the essential amino acid requirement of common carp (Wilson 1985).

The protein digestibility was found to be better or comparable to the reference diet for diets with lysine and methionine + cystine supplementation, up to 50\% replacement of fish meal protein with oilseed meal proteins. In case of oilseed meal containing diets without any amino acids supplementation digestibility of protein was recorded lower in comparison to those for the reference diet. However, individual supplementation of amino acids resulted in increased protein digestibility than for the diets without any amino acid supplementation. The apparent digestibility of protein decreased with increasing level of incorporation of oilseed meal protein without any amino acid supplementation.

The proximate composition of carcass of the experimental fish at the termination of the feeding trial resulted in significant increase in protein and fat in comparison to the initial values in all the dietary treatments. Carcass moisture content of the fish fed $50 \%$ oilseed meal protein diet with/without amino acid supplementation was lower and protein content was higher than those fed other experimental diets. The fish fed diets in which $50 \%$ fish meal protein was replaced by oilseed meal protein and supplemented with all three amino acids (lysine, methionine +cystine), resulted in higher protein and lipid and lower moisture deposition than those reared on the reference diet. Webster et al. (1995) however, did not find any significant difference in percentage of moisture, protein and fat in blue catfish, 
Ictalurus furcatus fed L-methionine supplemented soybean meal containing diets. Poston and Rumsey (1983) reported that feeding graded levels of tryptophan caused increased deposition of lipid and dry matter and lower ash and body protein in rainbow trout. Robinson (1991) observed no negative effects on percentage dressout or proximate composition of channel catfish fed diets containing cotton seed meal protein with/without supplemented lysine. He found an increase in percentage protein and reduction in percentage fat in channel catfish fed a feed containing 50\% cotton seed meal protein and lysine. In the present study, diets containing $50 \%$ oilseed meal protein with supplemental lysine, methionine + cystine resulted in significant increase in both protein and lipid in the carcass of the fish.

Deoiled copra meal cannot be utilised at a level of more than $20-30 \%$ of diet in raw condition without compromising growth of fish (Mukhopadhyay and Ray 1999). The factors which limit their incorporation at high levels are the presence of antinutritional factors, tannin and phytic acid and amino acid imbalance. The inclusion rate of copra meal could be increased up to $30-40 \%$ by eliminating/reducing the amount of tannin and phytic acid by proper processing prior to their incorporation (Mukhopadhyay and Ray 1999). It can further be concluded that rohu fingerlings are able to effectively utilise the supplemental amino acids and that up to $50 \%$ of fish meal protein can be replaced by deoiled copra meal proteins in the diets for rohu if the oilseed meal is properly processed (fermented) and supplemented with deficient amino acids.

\section{ACKNOWLEDGEMENTS}

I am grateful to the Indian Council of Agricultural Research, New Delhi (Project No. 4 (26)/92-ASR-I) and the University Grants Commission (DSA Programme) for financial support. Sincere thanks are due to Professor R.K. Mondal, Bose Institute, Calcutta for his kind help in analysis of amino acids.

\section{REFERENCES}

Andrews J.W., J.W. Page, 1974: Growth factors in the fish meal component of catfish diets. J. Nutr., 104: 1091-1096.

AOAC, 1990: Official methods of Analysis of AOAC. vol. I, [K. Helrich (ed.)], Associatio of Analytical Chemists, Inc., Arlington, VA. $15^{\text {th }}$ edn.

APHA, 1980: Standard methods for the examination of water and waste water. American Public Health Association, American Water Works Association and Water Pollution Control Federation, Washington DC. $15^{\text {th }}$ edn. 
Bolin D.W., R.P. King, F.W. Klosterman, 1952: A simplified method for the determination of chromic oxide $\left(\mathrm{Cr}_{2} \mathrm{O}_{3}\right)$ when used as a index substance. Science, 116: 634-635.

Das D., A. Das, 1993: Statistics in Biology and Physiology. Academic Publishers, Calcutta.

Fordiani T.R., H.G. Ketola, 1980: Effects of heat treatment of first limiting amino acids of soybean meal in trout diets. Abstr. $72^{\text {nd }}$ Ann. Meet. Amer. Soc. Animal Sci.: 196.

Mukhopadhyay N., A.K. Ray, 1996: The potential of deoiled sal (Shorea robusta) seed meal as a feedstuff in the pelleted feed of rohu, Labeo rohita (Hamilton) fingerlings. Aquaculture Nutrition, 2: 221-227.

Mukhopadhyay N., A.K. Ray, 1997: The apparent total and nutrient digestibility of sal (Shorea robusta) seed meal in rohu, Labeo rohita (Hamilton) fingerlings. Aquaculture Research, 28: 101-107.

Mukhopadhyay N., A.K. Ray, 1999: Utilization of copra meal in formulation of compounded diets for rohu, Labeo rohita (Hamilton) fingerlings. J. Appl. Ichthyol., (In press).

Murai T., H. Ogata, P. Kosutarak, S. Arai, 1986: Effects of amino acid supplementation and methanol treatment of utilization of soyflour by fingerling carp. Aquaculture, 56: 197-206.

NRC-NAS, 1983: Nutrient requirements of warm water fishes and shell fishes. National Academy Press, Washington DC.

New M.B., 1987: Feed and feeding of fish and shrimp. UN Development Programme FAO, Rome.

Nose T., 1979: Summary report on the requirements for essential amino acids for carp. In: Finfish Nutrition and Fishfeed Technology [J.E. Halverand, K. Tiews (eds.)], Heenemann, Berlin: 145156.

Poston H.A., G.L. Rumsey, 1983: Factors affecting dietary requirement and deficiency signs of L-tryptophan in rainbow trout. J. Nutr., 113: 2568-2577.

Robinson E.H., 1991: Improvement of cotton seed meal protein with supplemental lysine in feeds for channel catfish. J. Appl. Aqua., 1, 2: 1-14.

Rumsey G.L., H.G. Ketola, 1975: Amino acid supplementation of casein in diets of Atlantic salmon (Salmo salar) fry and of soybean meal for rainbow trout (Salmo gairdneri) fingerlings. J. Fish. Res. Bd Can., 32: 422-426.

Schanderi S.H., 1970: Method in food analysis. Academic Press, New York.

Shiau S.Y., J.L. Chuang, C.L. Sun, 1987: Inclusion of soybean meal in tilapia (Oreochromis niloticus $\times$ O. aureus) diets at two protein levels. Aquaculture, 65: 251-261.

Spyridakis P., R. Metailler, J. Gabaudan, A. Riaza, 1989: Studies on nutrient digestibility in European seabass (Dicentrarchus labrax). I. Methodological aspects concerning faeces collection. Aquaculture, 77: 61-70.

Steffens W., 1989: Principles in Fish Nutrition. Elis Horwood, Chichester, England.

Tacon A.G.J., 1985: Nutritional fish pathology. Morphological signs of nutritional deficiency and toxicity in farmed fish. In: The Report of UN Development Programme, FAO, Rome: 1-33.

Tacon A.G.J., 1993: Feed ingredients for warmwater fish: Fish meal and other processed feedstuffs. FAO Fisheries Circular, No. 856, FAO, Rome.

Tacon A.G.J., J.L Webster, C.A. Martinez, 1984: Use of solvent extracted sunflower seed meal in complete diets for fingerlings rainbow trout (Salmo gairdneri). Aquaculture, 43: 381-389.

Teshima S., A. Kanazawa, 1988: Nutritive value of methionine-enriched soybean plastein for Oreochromis niloticus fry. In: The Second International Symposium on Tilapia [R.S.V. Pullin, T. Bhukaswan, K. Tonguthai, J.L. Mclean (eds.)], ICLARM Proceedings 15, Manila, Philippines: 393-399.

Thebault H., 1985: Plasma essential amino acid changes in sea-bass (Dicentrarchus labrax) after feeding diets deficient and supplemented in L-methionine. Comp. Biochem. Physiol., 82A: 233237.

Viola S., S. Mokady, U. Rappaport, Y. Arieli, 1982: Partial or complete replacement of fishmeal by soyabean meal in feeds for intensive culture of carps. Aquaculture, 26: 223-236. 
Webster C.D., L.S. Goodgame-Tiu, J.H. Tidwell, 1995: Total replacement of fishmeal by soyabean meal, with varius percentages of supplemental L-methionine in diets for blue catfish, Ictalurus furcatus (Lesueur). Aquaculture Research, 26: 299-306.

Wheeler E.L., R.E. Ferrel, 1971: A method for phytic acid determination in wheat and wheat fractions. Cereal Chemistry, 48: 312-320.

Wilson R.P., 1985: Amino acid and protein requirements of fish. In: Nutrition and Feeding in Fish [C.B. Cowey, A.M. Mackie, J.G. Bell (eds.)]. Academic Press, London: 1-16.

Wu J.L., L. Jan, 1977: Comparison of the nutritive value of dietary proteins in Tilapia aurea. J. Fish. Soc. Taiwan, 5, 2: 55-60.

\author{
Nibedita MUKHOPDHYAY \\ POPRAWA JAKOŚCI BIAŁKA KOPRY (SUSZONY MIAŻSZ ORZECHA \\ COCOS NUCIFERA) WZBOGACONEJ AMINOKWASAMI W PASZACH \\ DLA PALCZAKÓW GRUBOWARGA, LABEO ROHITA (HAMILTON)
}

\title{
STRESZCZENIE
}

W zamkniętym systemie hodowlanym przeprowadzono ośmiotygodniowe badania żywieniowe w celu określenia efektów częściowego zastappienia białka mączki rybnej białkiem kopry (mączki kokosowej) wzbogaconej (lub nie) aminokwasami w żywieniu palczaków grubowarga, Labeo rohita (średnia masa 5,5 $\pm 0,19 \mathrm{~g}$ ). Przed dodaniem do paszy kopra była poddawana fermentacji przy udziale bakterii kwasu mlekowego (Lactobacillus acidophilus) dla zredukowania/eliminacji zawartych $w$ niej składników antyżywieniowych - taniny i kwasu fitynowego. Przygotowano dwanaście wariantów pasz (D1-D12), w których w różnym stopniu zastapiono białko mą̧czki rybnej białkem kopry (cztery zestawy pasz, z których każdy składal się z trzech wariantów odpowiadających 30, 40 i 50-procentowemu zastapieniu białek mączki rybnej białkiem kopry). Pasze od D1 do D3 nie byly wzbogacone aminokwasami. Lizyna zostala dodana do pasz od D4 do D6. Pasze od D7 do D9 zawierały metioninę-cystynę (łącznie), zaś warianty od D10 do D12 miały w swoim składzie lizynę oraz metionine-cystynę (łącznie). Lizyna oraz metionina-cystyna (lacznie) stanowily odpowiednio 5,7 oraz $3,1 \%$ bialek żywieniowych. Grupa ryb żywiona paszami bez dodatków aminokwasów, miała statystycznie istotnie niższy przyrost masy i SGR oraz wyższe FCR niż grupy ryb żywione innymi wariantami pasz. Dodatek lizyny oraz metioniny-cystyny do pasz, których 50\% białek mączki rybnej zostało zastapione przez bialka kopry (D12) w istotny sposób poprawil przyrost masy i FCR. Procentowy przyrost żywej masy oraz SGR różnily się statystycznie $(\mathrm{P}<0,01)$ od siebie u ryb żywionych paszami od DI0 do D12, do których dodano wszystkie trzy aminokwasy. Wyniki niniejszej pracy sugeruja że palczali grubowarga potrafia efektywnje wykorzystywać dodane do paszy aminokwasy, a białka kopry mogą zastappić do $50 \%$ białek mączki rybnej w paszach, jeżeli mączka jest wlaściwie fermentowana i wzbogacona egzogennymi aminokwasami.

Author's address:

Nibedita Mukhopadhyay $\mathrm{PhD}$, Research Associate

Aquacultural Engineering Section

Agricultural \& Food Engineering Department

Indian Institute of Technology

Kharagpur-721 302, India

e-mail: nibeditta@hotmail.com 